\title{
Faktor-Faktor yang Mempengaruhi Resiliensi Warga Binaan Pemasyarakatan Pria: Studi Literatur
}

\author{
Yunita Anggerina Koroh ${ }^{1}$, Megah Andriany ${ }^{1 *}$ \\ ${ }^{1}$ Departemen Ilmu Keperawatan, Fakultas Kedokteran, Universitas Diponegoro, Semarang, Indonesia \\ megahandriany@fk.undip.ac.id
}

\begin{abstract}
Introduction: Resilience has an important role for psychological balance of male inmates as a population which is more vulnerable to a decline in mental health. This is a descriptive qualitative study with a literature review research design.

Methods: This study was a literature review by examining ten literatures that had passed the screening process according to the specified inclusion criteria.

Results: The results of this study found that there are two factors which affecting the resilience of male inmates, namely protective factor and risk factor. The protective factors are internal factors: social competence and good self-acceptance; and external factor named social support. The risk factors are internal factor in the form of psychological character: impulsivity and external factor from the family namely history of childhood trauma. The resilience of male inmates is affected by two factors consisting of protective factors and risk factors. The protective factors contribute to the high resilience level and the risk factors contributes to the low resilience level of male inmates).
\end{abstract}

Keywords: Male Inmates, Prisoners, Protective Factor, Risk Factor, Resilience.

\section{Abstrak}

Latar belakang: Resiliensi berperan penting bagi keseimbangan psikologi WBP pria sebagai populasi yang rentan mengalami penurunan kesehatan mental. Studi ini bertujuan mengidentifikasi faktor-faktor yang mempengaruhi resiliensi WBP pria.

Metode: Studi ini merupakan studi literatur dengan menelaah sepuluh literatur setelah melewati proses screening sesuai kriteria inklusi yang ditetapkan.

Hasil: Hasil telaah literatur menemukan terdapat dua faktor yang mempengaruhi resiliensi WBP pria, yakni faktor protektif dan faktor risiko. Faktor protektif adalah faktor internal berupa kompetensi sosial dan penerimaan diri yang baik serta faktor eksternal berupa dukungan sosial yang diperoleh dari keluarga, teman dekat dan komunitas sekitar. Faktor risiko adalah faktor internal berupa adanya karakter psikologi yakni impulsivitas dan faktor eksternal berupa disfungsi keluarga dan riwayat trauma masa kecil. Resiliensi WBP pria dipengaruhi oleh faktor protektif yang berkontribusi positif terhadap pembentukan resiliensi WBP pria dan faktor risiko yang berdampak pada rendahnya resiliensi WBP pria.

Kata kunci: Faktor Protektif, Faktor Risiko, Warga Binaan Pemasyarakatan, Resiliensi. 


\section{PENDAHULUAN}

Warga Binaan Pemasyarakatan (WBP) pria merupakan populasi mayoritas yang ada di Lembaga Pemasyarakatan (Lapas). Umumnya, WBP pria mengalami hambatan dalam beradaptasi terhadap lingkungan Lapas maupun dalam upaya menerima status sebagai WBP sehingga mengalami stress (Maschi, Viola \& Koskinen, 2015). Pria memiliki harga diri yang tinggi dibanding wanita sehingga lebih mampu dalam menyelesaikan masalah emosional (Yau, Sun \& Cheng, 2012), namun tidak menutup kemungkinan bahwa WBP pria juga mengalami stres.

Kondisi stres WBP pria disebabkan oleh beberapa faktor. Faktor intrapersonal berupa rasa bersalah, kekhawatiran terhadap keluarga yang ditinggalkan, ketidakjelasan masa depan dan kesepian. Faktor interpersonal misalnya hubungan kurang harmonis antar WBP maupun dengan petugas Lapas serta kurangnya dukungan keluarga maupun teman. Faktor kelembagaan berupa kepadatan Lapas, kurangnya privasi dan layanan kesehatan yang tidak memadai. Faktor sosialbudaya berupa stigmatisasi masyarakat terhadap status WBP (Mansoor, Perwez, Swami \& Ramasheshan, 2015; Maschi, Viola\& Koskinen, 2015; Siswati \& Abdurohim, 2009).

Stresor berkepanjangan berefek pada munculnya gejala gangguan kejiwaan akibat ketidakmampuan WBP pria untuk beradaptasi di Lapas (Sharma, Prakash, Sengar \& Singh, 2015). Stres berkepanjangan menyebabkan munculnya gejala yang mengarah pada gangguan kejiwaan pada WBP pria. Gejala yang dialami yakni diantaranya $26,2 \%$ mengalami depresi, $42 \%$ mengalami pengembangan gangguan stres pasca-trauma dan 3,6\% menderita gangguan psikotik (Yi, Turney \&
Wildeman, 2017). Rata-rata WBP memiliki masalah kesehatan jiwa yang tinggi, yakni ditemukan terdapat 16 per 100.000 WBP melakukan bunuh diri dan sebanyak satu dari tujuh orang terdiagnosa psikosis dan depresi (Fazel, Hayes, Bartellas Clerici \& Trestman, 2016). Sebanyak 20,5\% dari 120 kasus kematian WBP di Indonesia diakibatkan karena bunuh diri, yang mana $20 \%$ kasus kematian terjadi pada WBP yang terdiagnosis depresi (Wirya \& Permata, 2017).

Salah satu faktor yang berkontribusi positif terhadap masalah kejiwaan yang dialami WBP pria adalah resiliensi. Resiliensi merupakan kemampuan individu untuk beradaptasi positif terhadap kejadian yang berat atau masalah yang terjadi dalam kehidupan (Reivich \& Shatte, 2002). Resiliensi merupakan topik penting yang telah diteliti oleh para peneliti selama bertahun-tahun, terutama pada populasi umum. Penelitian terkait faktor-faktor yang mempengaruhi resiliensi dengan WBP pria sebagai subjek penelitian masih terbatas dan menunjukkan hasil yang berbeda. Riza dan Herdiana (2012) memaparkan faktor pembentuk resiliensi WBP pria adalah dukungan sosial dari orang terdekat dan religiusitas yang tinggi. Huang, $\mathrm{Wu}, \mathrm{Wu}$, Yang, Zheng dan Wu (2020) menjelaskan faktor pembentuk resiliensi WBP pria adalah faktor eksternal berupa dukungan sosial orang terdekat dan faktor internal berupa penerimaan diri. Sulaiman, Ibrahim, Nen, Samon dan Alavi (2016) menjelaskan resiliensi WBP pria dipengaruhi oleh dukungan sosial (dari keluarga, pekerja di Lapas dan penerimaan dari komunitas) serta efikasi diri dan optimisme.

Penelitian-penelitian di atas menunjukkan beberapa hasil terkait faktor-faktor yang mempengaruhi 
resiliensi WBP pria dan belum ditemukan hasil penelitian yang menelaah hal tersebut. Oleh karena itu diperlukan suatu telaah terhadap berbagai referensi yang ada untuk mengumpulkan berbagai faktor yang mempengaruhi resiliensi WBP pria. Studi ini perlu dilakukan mengingat WBP pria adalah populasi yang rentan mengalami masalah psikologis. Hasil penelitian ini diharapkan memberikan referensi ilmiah untuk memperkuat deteksi dini, intervensi awal dan treatment yang diperlukan untuk meningkatkan resiliensi WBP di Lapas. Kontribusi akhir dari hasil ini adalah masalah kesehatan mental yang umum terjadi pada WBP pria di Lapas dapat teratasi.

\section{METODE}

Jenis penelitian ini adalah studi literatur, yakni tinjauan komprehensif dari hasil penelitian-penelitian sebelumnya mengenai topik tertentu (Denney \& Tewksbury, 2013). Pencarian literatur dalam penelitian ini diakses oleh penulis dari penyedia dokumen elektronik seperti Google Scholar, Scopus, EBSCO dan Science Direct. Peneliti mencari literatur dengan menggunakan kata kunci "resilience, resilience factor, resilience protective factor, resilience risk factor, maleinmates dan male-prisoner".

Kriteria inklusi ditetapkan untuk membatasi pencarian sehingga dapat mempermudah penulis menemukan literatur yang diinginkan (Snyder, 2019). Kriteria inklusi yang ditetapkan penulis adalah: 1) Bahasa yang digunakan adalah Bahasa Inggris dan Bahasa Indonesia; 2) Jangka waktu publikasi adalah 10 tahun, yakni tahun 2010-2020; 3) Literatur berupa artikel ilmiah hasil dari penelitian primer dan tersedia dalam bentuk fulltext; 4) Hasil penelitian dapat berupa penelitian kualitatif maupun kuantitatif;
5) Subjek penelitian adalah WBP pria; 6) Tema yang dibahas berkaitan dengan topik faktor-faktor yang mempengaruhi resiliensi pada WBP pria.

\section{HASIL}

Peneliti menemukan sepuluh literatur yang akan ditelaah yang digambarkan pada diagram berikut:

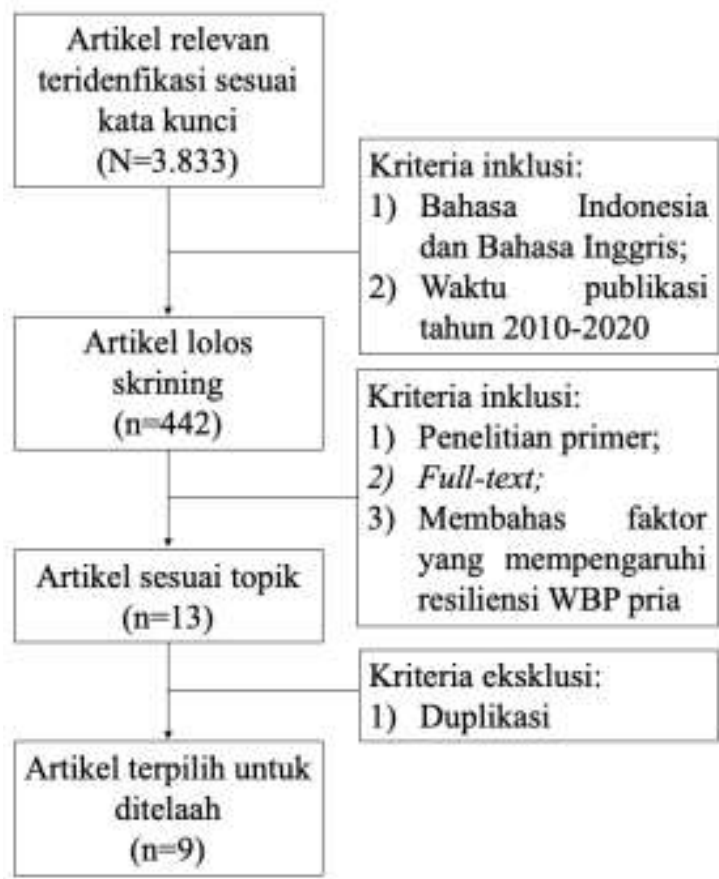

Gambar 1. Diagram Proses Seleksi Literatur 
Tabel 1. Identitas Literatur dalam Kajian

\begin{tabular}{|c|c|c|c|c|}
\hline No. & $\begin{array}{c}\text { Penulis dan } \\
\text { Tahun }\end{array}$ & Tahun & Judul Artikel & Nama Jurnal \\
\hline 1. & $\begin{array}{l}\text { Vladimir Carli, } \\
\text { Nikolona } \\
\text { Jovanovic, Anja } \\
\text { Podlesek, Alec } \\
\text { Roy, Zoltan } \\
\text { Rihmer, Stefania } \\
\text { Maggi, Dragan } \\
\text { Marusic, Caterina } \\
\text { Cesaro, Andrej } \\
\text { Marusic dan Marco } \\
\text { Sarchiapone }\end{array}$ & 2010 & $\begin{array}{l}\text { The Role of Impulsivity in Self- } \\
\text { Mutilators, Suicide Ideators and } \\
\text { Suicide Attempters - A Study of } \\
1265 \text { Male Incarcerated Individuals }\end{array}$ & $\begin{array}{l}\text { Journal of } \\
\text { Affective } \\
\text { Disorders }\end{array}$ \\
\hline 2. & $\begin{array}{l}\text { Muhammad } \\
\text { Riza dan Ike } \\
\text { Herdiana }\end{array}$ & 2013 & $\begin{array}{l}\text { Resiliensi pada Narapidana Laki- } \\
\text { Laki di Lapas Klas } 1 \text { Medaeng }\end{array}$ & $\begin{array}{l}\text { Jurnal Psikologi } \\
\text { Kepribadian dan } \\
\text { Sosial } \\
\end{array}$ \\
\hline 3. & $\begin{array}{l}\text { Refi Ristiana Purba } \\
\text { Devi dan Aad Satria } \\
\text { Permadi }\end{array}$ & 2015 & $\begin{array}{l}\text { Resiliensi pada Narapidana Dewasa } \\
\text { di Lembaga Pemasyarakatan Klas } \\
\text { IIa Sragen }\end{array}$ & $\begin{array}{c}\text { eprints } \\
\text { Universitas } \\
\text { Muhammadiyah } \\
\text { Surakarta } \\
\end{array}$ \\
\hline 4. & $\begin{array}{l}\text { Wan Shahrazad } \\
\text { Wan Sulaiman, } \\
\text { Fauziah Ibrahim, } \\
\text { Mohamad Suhaimi } \\
\text { Mohd, Salina Nen, } \\
\text { Norulhuda Sarnon } \\
\text { dan Khadijah Alavi }\end{array}$ & 2016 & $\begin{array}{l}\text { Rehabilitation Through Parole } \\
\text { System in Malaysia: The Role of } \\
\text { Optimism as Mediating Variable in } \\
\text { the Relationship between Self- } \\
\text { Efficacy and Resilience }\end{array}$ & $\begin{array}{l}\text { Jurnal Psikologi } \\
\text { Malaysia }\end{array}$ \\
\hline 5. & $\begin{array}{l}\text { Sarlina Kurniati } \\
\text { Tunliu, Diana } \\
\text { Apipidely dan } \\
\text { Feronika Ratu }\end{array}$ & 2019 & $\begin{array}{l}\text { Dukungan Sosial Keluarga terhadap } \\
\text { Resiliensi pada Narapidana di } \\
\text { Lembaga Pemasyarakatan Klas IIa } \\
\text { Kupang }\end{array}$ & $\begin{array}{l}\text { Journal of } \\
\text { Health and } \\
\text { Behavioral } \\
\text { Science }\end{array}$ \\
\hline 6. & $\begin{array}{l}\text { Aisyah Nurul } \\
\text { Hafidah dan } \\
\text { Margaretha }\end{array}$ & 2020 & $\begin{array}{l}\text { Faktor Resiliensi } r \\
\text { Pemasyarakatan dalam Perspektif } \\
\text { Teori Bioekologi Bronfenbenner: } \\
\text { Pentingnya Faktor Dukungan Sosial }\end{array}$ & $\begin{array}{l}\text { Psyche: Jurnal } \\
\text { Psikologi } \\
\text { Universitas } \\
\text { Muhammadiyah } \\
\text { Lampung } \\
\end{array}$ \\
\hline 7. & $\begin{array}{l}\text { Nancy Wolff dan } \\
\text { Francisco Caravaca } \\
\text { Sánchez }\end{array}$ & 2019 & $\begin{array}{l}\text { Associations among Psychological } \\
\text { Distress, Adverse Childhood } \\
\text { Experiences, Social Support and } \\
\text { Resilience in Incarcerate Men }\end{array}$ & $\begin{array}{l}\text { Criminal Justice } \\
\text { and Behavior }\end{array}$ \\
\hline 8. & $\begin{array}{l}\text { Dr. Bartlomiej } \\
\text { Skowronski dan Dr. } \\
\text { Elżbieta Talik }\end{array}$ & 2020 & $\begin{array}{l}\text { Resilience and Quality of Life } \\
\text { Among People Serving Prison } \\
\text { Sentences in Penitentiary } \\
\text { Institutions: The Mediating Role of } \\
\text { Social Support. }\end{array}$ & $\begin{array}{l}\text { International } \\
\text { Journal of } \\
\text { Social } \\
\text { Research }\end{array}$ \\
\hline 9. & $\begin{array}{l}\text { Yuanni Huang, } \\
\text { Ruibin Wu, } \\
\text { Junkai Wu, } \\
\text { Qingwen Yang, } \\
\text { Shukai Zheng } \\
\text { dan Kusheng } \\
\text { Wu }\end{array}$ & 2020 & $\begin{array}{l}\text { Psychological Resilience, Self- } \\
\text { Acceptance, Perceived Social } \\
\text { Support and Their Associations } \\
\text { with Mental Health of Incarcerated } \\
\text { Offenders in China }\end{array}$ & $\begin{array}{l}\text { Asian Journal } \\
\text { of Psychiatry }\end{array}$ \\
\hline 10. & $\begin{array}{l}\text { Alec Roy, } \\
\text { Vladimir Carli } \\
\text { dan Marco } \\
\text { Srchiapone }\end{array}$ & 2011 & $\begin{array}{l}\text { Resilience Mitigates the Suicide } \\
\text { Risk Associated with Childhood } \\
\text { Trauma }\end{array}$ & $\begin{array}{c}\text { Journal } \\
\text { Affective } \\
\text { Disorders }\end{array}$ \\
\hline
\end{tabular}


Hasil telaah literatur menunjukkan faktorfaktor yang mempengaruhi resiliensi WBP pria yang dirangkum pada tabel 1 .

Tabel 1. Faktor yang Mempengaruhi Resiliensi WBP Pria

\begin{tabular}{ll}
\hline Kategori & \multicolumn{1}{c}{$\begin{array}{c}\text { Faktor yang } \\
\text { Mempengaruhi }\end{array}$} \\
\hline Protektif & Faktor internal \\
& Kompetensi sosial \\
& Penerimaan diri \\
& Faktor eksternal \\
& Dukungan sosial \\
\hline Risiko & Faktor internal \\
& Impulsivitas \\
& Faktor eksternal \\
& Disfungsi keluarga \\
& Riwayat trauma masa \\
& kecil \\
\hline
\end{tabular}

\section{PEMBAHASAN}

Hasil studi ini menemukan terdapat dua faktor yang mempengaruhi resiliensi, yaitu faktor protektif dan faktor risiko. Faktor protektif (protective factors) merupakan faktor yang berkontribusi terhadap meningkatnya resiliensi individu (Troy \& Mauss, 2011). Individu saat berada dalam kondisi depresif membutuhkan faktor protektif yang berperan penting meningkatkan perilaku positif individu. Adanya faktor protektif menjadikan individu menghindari peluang untuk melakukan hal negatif dan mencapai kondisi resilien (Wright \& Masten, 2005; Brackenreed, 2013).

Faktor protektif resiliensi individu dapat berupa faktor internal individu dan faktor eksternal individu (Brackenreed, 2013; Troy \& Mauss, 2011; Wright \&

Masten, 2005). Faktor protektif internal resiliensi berupa kompetensi sosial (Devi \& Permadi, 2015; Hafidah \& Margaretha, 2020). Devi dan Permadi (2015) menjelaskan WBP pria yang memiliki kompetensi sosial yang baik adalah WBP yang memiliki tingkat resiliensi yang tinggi. Kompetensi sosial yang dimaksud adalah kemampuan WBP pria dalam bersosialisasi dan mampu menjalin komunikasi interpersonal yang baik. WBP dengan kemampuan interaksi sosial yang baik, yang memiliki selera humor, empati, fleksibilitas adaptif, dan tidak temperamental mengindikasikan subjek sebagai individu yang resilien (Wright \& Masten, 2005). Kompetensi ini sangat dibutuhkan di dalam Lapas untuk menghindari dampak buruk seperti terlibat perkelahian (Hafidah \& Margaretha, 2020).

WBP pria dalam menghadapi kesukaran selama beradaptasi di Lapas juga membutuhkan dukungan dari komunitas yang ada di sekitar (Hafidah \& Margaretha, 2020). Individu yang memiliki relasi yang positif dengan orang lain adalah individu yang memiliki kemampuan meregulasi emosi yang baik dan dapat mengendalikan amarah. Individu seperti ini umumnya dapat menerima arahan positif yang didapatkan di dalam komunitas yang memberi dukungan positif (Everall, Altrows \& Paulson, 2006). Sebaliknya, adanya ketidakstabilan emosi, agresivitas, sikap tertutup dan permusuhan sebagai indikator rendahnya kompetensi sosial individu berhubungan signifikan dengan rendahnya resiliensi WBP pria (Carli et al., 2010).

Faktor protektif internal lainnya adalah penerimaan diri (Huang et al., 2020). Chen, Liu, Zhan dan Li, (2017) menjelaskan penerimaan diri merujuk pada kognisi terkait penilaian diri aktual dan penerimaan diri aktual yang terwujud dalam emosi dan sikap individu. Individu yang tidak menerima diri sendiri akan mudah untuk memiliki rasa rendah diri dan berdampak bagi ketidakseimbangan kesehatan mental individu. Sebaliknya, tingkat penerimaan diri yang lebih tinggi 
dapat mengurangi tingkat depresi individu dan membuat individu lebih bahagia (Huang et al., 2020).

Umumnya WBP memiliki tingkat penerimaan diri yang rendah dibanding populasi lain. Penerimaan diri oleh WBP pria dipengaruhi oleh faktor demografi, seperti tempat tinggal dan pekerjaan. WBP yang tinggal di desa dan WBP yang bekerja sebagai pegawai pemerintah adalah individu dengan tingkat penerimaan diri yang rendah. Sebaliknya, WBP yang tinggal di kota dan WBP yang bekerja sebagai pengusaha memiliki tingkat penerimaan diri yang tinggi. WBP dengan riwayat tempat tinggal di kota dan bekerja sebagai pengusaha umumnya memiliki kondisi sosial-ekonomi yang lebih baik. Hal ini membuat WBP lebih banyak mendapatkan dukungan sehingga membantu meningkatkan tingkat penerimaan diri. Tingkat penerimaan diri oleh WBP pria yang tinggi berjalan linear dengan tingkat resiliensi yang tinggi (Huang et al., 2020).

Faktor protektif lainnya adalah faktor protektif eksternal berupa dukungan sosial. Zhang dalam Huang et al. (2020) mendefinisikan dukungan sosial sebagai koneksi spiritual dan material antara individu dan berbagai aspek masyarakat, seperti keluarga, teman, pemerintah, dan lain-lain. Dukungan sosial yang dirasakan terutama menekankan pada pemahaman diri individu dan perasaan mendapatkan dukungan sosial yang dapat memprediksi tingkat kesehatan mental individu lebih dari dukungan sosial yang sebenarnya. Dukungan sosial dapat bertindak sebagai buffer antara peristiwa kehidupan yang merugikan dan kesehatan mental serta mengurangi kejadian depresi (Huang et al., 2020). Analisa terkait dukungan sosial yang mempengaruhi resiliensi WBP pria menunjukkan adanya perbedaan sumber dan bentuk dukungan sosial yang diperoleh. Peneliti menyimpulkan kemungkinan perbedaan ini disebabkan oleh karena terdapatnya perbedaan instrumen yang digunakan.

Huang et al. (2020) melaporkan dukungan sosial yang dirasakan oleh WBP umumnya rendah. Hal ini mengindikasikan dukungan sosial yang diberikan kepada WBP umumnya rendah dan kemungkinan disebabkan oleh diskriminasi dari keluarga atau teman atau pasangan atau pihak-pihat tersebut menolak memberikan bantuan. Penelitian ini juga membuktikan faktor sosio-demografi berperan penting terhadap dukungan sosial bagi WBP, seperti faktor usia, status pernikahan dan status finansial. WBP yang mendapatkan dukungan sosial yang baik adalah WBP yang berusia dewasa, WBP yang menikah atau memiliki pasangan dan WBP yang memiliki status ekonomi yang baik.

WBP yang berusia dewasa umumnya mendapatkan dukungan sosial yang tinggi. Seiring bertambahnya usia, WBP memiliki pemahaman yang lebih mendalam tentang kesalahan yang dilakukan. Hal ini kemudian berefek pada munculnya lebih banyak simpati dan bantuan dari komunitas sekitar terhadap WBP (Huang et al., 2020). WBP yang telah menikah atau memiliki pasangan mendapatkan dukungan sosial yang tinggi dikarenakan banyaknya perhatian dan dukungan yang diperoleh dari pasangan dan keluarga (Huang et al., 2020). Peran keluarga yang memberikan fungsi merawat dan mendukung membuat individu merasa lebih dicintai, dipedulikan dan merasa lebih berharga (Huang et al., 2020; Markson, Lösel, Souza \& Lanskey, 2015; Walsh, 2001). WBP dengan status sosial-ekonomi yang baik mendapatkan dukungan sosial yang baik oleh karena kecukupan finansial membuat WBP mendapatkan dukungan material untuk memenuhi kebutuhan (Huang et al., 2020).

Tunliu, Apipidely dan Ratu (2019) melaporkan tingginya dukungan sosial WBP pria. Penelitian ini menyatakan bahwa dukungan sosial dari keluarga merupakan faktor penting yang paling 
berkontribusi terhadap terbentuknya resiliensi WBP pria. Faktor keluarga berperan penting sebagai faktor protektif untuk meningkatkan resiliensi individu. Keluarga sebagai caregiver menyediakan fungsi merawat dan mendukung individu yang sedang berhadapan dengan kesulitan. Arahan berupa informasi positif dari keluarga mengarahkan individu untuk berperilaku positif dan adaptif (Walsh, 2001). Sejalan dengan penelitian tersebut, hasil penelitian Riza dan Herdiana (2012) mengungkapkan rendahnya resiliensi pada WBP pria diakibatkan karena WBP tidak mendapat dukungan sosial dari keluarga. WBP yang tidak mendapatkan dukungan sosial dari keluarga (yang belum menerima kenyataan pemenjaraan yang dialami subjek) mendapatkan dukungan sosial dari teman dekat/kekasih. Hal ini turut berkontribusi meningkatkan resiliensi WBP pria.

Sulaiman et al. (2016) menegaskan dukungan sosial tidak hanya diperoleh WBP pria dari keluarga atau orang terdekat saja namun juga dari petugas Lapas dan sesama penghuni Lapas. Senada dengan hal ini, penelitian Hafidah dan Margaretha (2020) melaporkan WBP pria juga mendapatkan dukungan sosial dari komunitas di Lapas. Pergaulan selama di Lapas menentukan arah masa depan WBP pria. Individu yang terlibat pergaulan positif, yang sungguh-sungguh mengikuti arahan selama pembinaan adalah WBP yang memiliki perubahan ke arah lebih baik pada masa reintegrasi WBP tersebut ke dalam masyarakat (Hafidah \& Margaretha, 2020; Sulaiman et al., 2016). Hafidah dan Margaretha (2020) menyatakan semakin tinggi bantuan yang diperoleh WBP pria maka semakin tinggi pula kemampuan WBP dalam mengatasi masalah. WBP yang mampu mengatasi masalah akan berujung pada tercapainya kondisi resilien. WBP yang mendapatkan dukungan sosial yang baik akan menjadi individu yang resilien dan berdampak positif pada perubahan ke arah yang lebih baik, bahkan memiliki kualitas hidup yang baik pula (Hafidah \& Margaretha, 2020; Skowronski \& Talik, 2020). Hubungan antara resiliensi dan kualitas hidup WBP pria terletak pada peran dukungan sosial yang memediasi kedua variabel tersebut. Hal ini bergantung pada keinginan WBP pria untuk mendapatkan bantuan dari orang lain (sebagai kebutuhan) dan menggunakan bantuan itu seefektif mungkin (Skowronski \& Talik, 2020).

Bentuk dukungan sosial yang diperoleh WBP pria dapat berupa dukungan sosial objektif maupun subjektif (Hafidah \& Margaretha, 2020). Aspek dukungan sosial yang paling berpengaruh adalah dukungan sosial objektif berupa dukungan emosional dari keluarga (Hafidah \& Margaretha, 2020). Hal berbeda diungkapkan oleh penelitian lain yang menyatakan aspek dukungan sosial (global, informasional, instrumental dan appraisal) mempengaruhi resiliensi WBP pria, kecuali dukungan sosial berupa dukungan emosional (Skowronski \& Talik, 2020). Penelitian lain juga mengungkapkan yang paling berkontribusi positif terhadap resiliensi WBP pria adalah dukungan sosial berupa dukungan penghargaan (Tunliu, Apipidely \& Ratu, 2019).

Faktor risiko merupakan faktor yang berkontribusi negatif terhadap pertahanan diri individu saat berhadapan dengan stresor (Brackenreed, 2013). Faktor risiko merupakan pencetus individu menjadi rapuh dan berpotensi melakukan hal buruk saat berhadapan dengan stresor. Hal ini berdampak pada ketidakseimbangan psikologis yang dimiliki individu oleh karena rendahnya resiliensi yang dimiliki individu (Brackenreed, 2013; Wright \& Masten, 2005). Faktor risiko yang berpengaruh pada resiliensi individu dapat berupa faktor internal dan faktor eksternal (Masten, 2014). Faktor risiko berefek pada rendahnya tingkat resiliensi individu ketika menghadapi kejadian depresif dan menjadi 
katalis bagi seseorang dalam bertindak maladaptif (Brackenreed, 2013). Faktor risiko internal terhadap resiliensi WBP pria, yakni impulsivitas (Carli et al., 2010). Moeller, Barratt, Dougherty dan Schmitz, dan Swann (2001) mendefinisikan impulsivitas sebagai "kecenderungan terhadap reaksi yang cepat, tidak terencana terhadap rangsangan internal atau eksternal tanpa memperhatikan konsekuensi negatif'. WBP pria dengan tingkat impulsivitas yang tinggi adalah WBP yang tidak resilien.

Carli et al. (2010) menjabarkan WBP pria dengan impulsivitas yang tinggi adalah WBP yang tidak memiliki pasangan atau bercerai, tidak bekerja atau pengangguran, berusia lebih muda dan yang memiliki riwayat kekerasan (pelaku atau korban perlakuan kekerasan) selama di penjara. WBP dengan impulsivitas yang tinggi berdampak pada timbulnya ide bunuh diri (suicide ideation/SI) dan percobaan bunuh diri (suicide attemper/SA). WBP pria dengan impulsivitas tinggi dan memiliki ide bunuh diri mayoritas adalah individu yang mengalami depresi dan memiliki resiliensi yang rendah. Sebaliknya, WBP yang resilien adalah WBP dengan impulsivitas yang rendah dan merupakan WBP dengan rata-rata usia di atas empat puluh satu tahun, memiliki pasangan (menikah atau sedang menjalin hubungan) dan baru pertama kali dipenjara.

Faktor risiko lainnya adalah faktor risiko eksternal, salah satunya adalah faktor keluarga. Keluarga seharusnya memiliki fungsi merawat dan mendukung anggota keluarga (Walsh, 2001). Realitanya, terdapat keluarga yang tidak mampu menghadirkan fungsi ini sehingga berdampak negatif pada anggota keluarga. Salah satu faktor keluarga adalah trauma masa kecil yang berhubungan signifikan dengan resiliensi WBP pria yang rendah (Roy, Carli \& Sarchiapone, 2011; Walsh, 2001; Wolff \& Sánchez, 2019). Trauma masa kecil merupakan faktor risiko yang berkontribusi terhadap rendahnya resiliensi WBP pria (Roy, Carli \& Sarchiapone, 2011; Wolff \& Sánchez, 2019). Roy, Carli \& Sarchiapone menyatakan WBP pria dengan riwayat trauma dan mengalami kesulitan semasa kecil hingga berusia delapan belas tahun cenderung memiliki resiliensi yang rendah. Jenis trauma masa kecil yang dialami antara lain pelecehan emosional, pelecehan fisik, pelecehan seksual, dan pengabaian emosional.

Wolff dan Sánchez (2019) juga menyatakan trauma masa kecil berhubungan signifikan dengan kemampuan WBP pria dalam menghadapi tekanan psikologis selama berada. WBP pria dengan riwayat trauma masa kecil cenderung tidak mampu beradaptasi dan bertahan selama di Lapas karena memiliki resiliensi yang rendah. Wolff dan Sánchez menspesifikasikan jenis trauma masa kecil yang dialami WBP seperti riwayat orangtua minum alkohol berlebihan, orangtua menggunakan obat terlarang, orangtua meninggal, orangtua dipenjara, mengalami pelecehan emosional, fisik, dan seksual.

Briere, Agee dan Dietrich (2016) menyatakan trauma masa kecil berhubungan erat dengan kesehatan mental WBP (Wolff \& Sánchez, 2019). Carli et al. (2010) juga menjelaskan WBP pria dengan trauma masa kecil dan memiliki sifat tertutup cenderung berasosiasi terhadap perilaku atau ide bunuh diri. Namun, tidak semua WBP dengan trauma masa kecil memiliki perilaku bunuh diri oleh karena memiliki resiliensi yang tinggi sebagai faktor protektif (Roy, Carli \& Sarchiapone, 2011). Roy, Carli dan Sarchiapone menyatakan resiliensi berperan penting dalam memitigasi risiko perilaku bunuh diri pada WBP pria yang mengalami trauma masa kecil. Terkait ide dan perilaku bunuh diri, resiliensi berperan sebagai faktor protektif yang melindungi WBP dari 
perilaku menyimpang seperti munculnya ide dan perilaku bunuh diri.

\section{KESIMPULAN DAN SARAN}

Resiliensi WBP pria dipengaruhi oleh faktor protektif yang berkontribusi terhadap meningkatnya resiliensi dan faktor risiko yang berkontribusi terhadap rendahnya resiliensi WBP pria. Faktor protektif dan risiko tersebut berasal dari internal dan eksternal individu. Faktor protektif internal dapat berupa kompetensi sosial dan penerimaan diri; faktor protektif eksternal dapat berupa dukungan sosial yang dapat diperoleh dari keluarga, teman dekat maupun komunitas sekitar. Faktor risiko internal adalah adanya perilaku impulsivitas yang tinggi dan faktor eksternal berupa disfungsi keluarga dan riwayat trauma masa kecil pada WBP pria.

Peneliti berharap agar penelitian ini dapat menjadi acuan bagi profesi terkait di Lapas untuk memperkuat deteksi dini faktor-faktor yang mempengaruhi resiliensi WBP, merencanakan intervensi awal dan memberikan treatment yang diperlukan serta menerapkan kebijakan yang sesuai untuk meningkatkan resiliensi WBP di Lapas. Secara khusus, hasil dari studi literatur ini diharapkan akan menjadi referensi bagi perawat sebagai tenaga kesehatan yang membantu WBP pria dalam beradaptasi di Lapas. Peneliti juga berharap hasil telaah ini dapat dijadikan sebagai data dasar bagi pengembangan penelitian selanjutnya terkait resiliensi WBP pria di Lapas.

\section{DAFTAR PUSTAKA}

Brackenreed, D. (2013). Resilience and risk. International Education Studies, 3(3), 111-121.

Briere, J., Agee, E., \& Dietrich, A. (2016). Cumulative trauma and current posttraumatic stress disorder status in general popsulation and inmate samples. Psychological Trauma: Theory, Research, Practice, and Policy, 8, 439-446. doi:10.1037/ tra0000107

Carli, V., Jovanović, N., Podlešek, A., Roy, A., Rihmer, Z., Maggi, S., Marusic, D., Cesaro, C., Marusic, A., Sarchiapone, M. (2010). The role of impulsivity in self-mutilators, suicide ideators and suicide attempters: A study of 1265 male incarcerated individuals. Journal of Affective Disorders, 123(1-3), 116-122. doi: 10.1016/j.jad.2010.02.119

Chen, S., Liu, J., Zhan, Z., Li, Z. (2017). Self-acceptance and associated factors among Chinese women with breast cancer. Journal of Clinical Nursing, 26(11-12), 1516-1523. doi: 10.1111/jocn. 13437

Denney, A. S. \& Tewksbury, R. (2013). How to write a literature review. Journal of Criminal Justice Education, 24(3), 1-17.

Devi, R. R. P. \& Permadi, A. S. (2015). Resiliensi pada narapidana dewasa di Lembaga Pemasyarakatan Klas IIA Sragen. Diperoleh dari http://eprints.ums.ac.id/.

Everall, R. D., Altrows, K. J., \& Paulson, B. L. (2006). Creating a future: A study of resilience in suicidal female adolescents. Journal of Counseling and Development, 84, 461-472.

Fazel, S., Hayes, A., Bartellas, K., Clerici, M., \& Trestman, R. (2016). The mental health of prisoners: A review of prevalence, adverse outcomes and interventions. Traumatology (tallahass fla) 3, 871-81.

Hafidah, A. N., \& Margaretha. (2020). Faktor resiliensi klien pemasyarakatan 
dalam perspektif Teori Bioekologi Bronfenbenner: Pentingnya faktor dukungan sosial. Jurnal Psikologi, 2(1), 52-68.

Huang, Y., Wu, R., Wu, J., Yang, Q., Zheng, S., \& Wu, K. (2020). Psychological resilience, selfacceptance, perceived social support and their associations with mental health of incarcerated offenders in China. Asian Journal of Psychiatry, 52(102166).

doi: 10.1016/j.ajp.2020.102166.

Mansoor, M., Perwez, S. K., Swam, T. N., \& Ramasheshan. (2015). A critical review on role of prison environment on stress and psychiatric problems among prisoners. Mediterranean Journal Social Sciences, 6(1), 218-223.

Markson, L., Lösel, F., Souza, K., \& Lanskey, C. (2015). Male prisoners' family relationships and resilience in resettlement. Criminology and Criminal Justice, 15(4), 423-441. doi: $10.1177 / 1748895814566287$.

Maschi, T., Viola, D., \& Koskinen, L. (2015). Trauma, stress, and coping among older adults in prison: Towards a human rights and intergenerational family justice action agenda. Traumatology (Tallahass fla), 21, 188200.

Moeller, F. G., Barratt, E. S., Dougherty, D. M., Schmitz, J. M., \& Swann, A. C. (2001). Psychiatric aspects of impulsivity. The American Journal of Psychiatry, 158(11), 1783-93. doi: 10.1176/appi.ajp.158.11.1783

Masten A. S. (2014). Global perspectives on resilience in children and youth. Child Development, 85(1), 6-20.

Reivich, K., \& Shatte, A. (2002). The resiliency factor: 7 keys to finding your inners strength and overcoming life's hurdles. New York: Three Rivers Press.

Riza, M., \& Herdiana, I. (2012). Resiliensi pada narapidana laki-laki di Lapas Klas 1 Medaeng. Jurnal Psikologi Kepribadian dan Sosial, 1(3), 142-147.

Roy, A., Carli, V., \& Sarchiapone, M. (2011). Resilience mitigates the suicide risk associated with childhood trauma. Journal of Affective Disorders, 133(3), 591-594.

doi: 10.1016/j.jad.2011.05.006.

Sharma, N., Prakash, O., Sengar, K. S., \& Singh, A. R. (2015). A study of mental health problems in criminals in terms of Depression, Anxiety and Stress". Glob $J$ Hum Soc SciRes, 15(9), 17-22.

Siswati, T. I, \& Abdurrohim. (2009). Masa hukuman dan stress pada Narapidana. Proyeksi, 4(02), 95- 106.

Skowronski, B., \& Talik, E. (2020). Resilience and quality of life among people serving prisons sentences in penitentiary institutions: The mediating role of social support. International Journal of Social Research, 4(44), 113.

Snyder, H. (2019). Literature review as a research methodology: An overview and guidelines. Journal of Business Research, 104, 333-339. doi: 10.1016/j.jbusres.2019.07.039.

Sulaiman, W. S. W., Ibrahim, F., Nen, S., Samon, N., \& Alavi, K. (2016). Rehabilitation through parole system in Malaysia: The role of optimism as mediating variable in the relationship between self-efficacy and resilience". Journal Psychology Malaysia, 30(2), 141-152. 
Troy, A. S., \& Mauss, I. B. (2001). Resilience in the face of stress: emotion regulation as a protective factor". In S. M. Southwick, B. T Litz, D., Charmey dan

Tunliu, S. K, Aipipidely, D., \& Ratu, F. (2019). Dukungan sosial keluarga terhadap resiliensi pada narapidana di Lembaga Pemasyarakatan Klas IIa Kupang". Journal of Health and Behavioral Science, 1(2), 68-82.

Walsh, F. (2001). Family resilience: A collaborative approach in response to stressful life change. In Southwick S. M., Litz B. T., Charney, D. and Friedman, M. J. Resilience and mental health: Challenges across lifespan. UK: Cambridge University Press.

Wirya, A., \& Permata, A. (2017). Kematian tahanan, kegagalan pemidanaan. Jakarta: Lembaga Bantuan Hukum Masyarakat". Diperoleh dari https://lbhmasyarakat.org/wpcontent/uploads/2017/03/KematianTahanan-Kegagalan-Pemidanaan-1.pdf
Wolff, N., \& Sánchez. F. C. (2019). Associations among psychological distress, adverse childhood experiences, social support, and resilience in incarcerate men. Criminal Justice and Behavior 2019; 20(10):120. doi: $10.1177 \% 2 \mathrm{~F} 0093854819876008$.

Wright, M. O., \& Masten, A. S. (2005). Resilience processes in development. In: S. Goldstein, R. B. Brooks (eds). Handbook of resilience in children. Boston: Springer.

Yau, H. K., Sun, H. \& Cheng, A. L. F. (2012). Relationships among academic, social and psychological adjustments to university life: Comparisons across gender. Tertiary Education and Management, 18(2), 97-113. doi: $10.1080 / 13583883.2011 .629676$

Yi, Y., Turney, K., Wildeman, C. (2017). Mental health among jail and prison inmates. American Journal of Men's Health, 11(4), 900-909. 